\title{
Pollination services in the UK: how important are honeybees?
}

Article

Accepted Version

Breeze, T. D., Bailey, A. P., Balcombe, K. G. and Potts, S. G. (2011) Pollination services in the UK: how important are honeybees? Agriculture, Ecosystems and Environment, 142 (34). pp. 137-143. ISSN 0167-8809 doi:

https://doi.org/10.1016/j.agee.2011.03.020 Available at https://centaur.reading.ac.uk/25072/

It is advisable to refer to the publisher's version if you intend to cite from the work. See Guidance on citing.

To link to this article DOI: http://dx.doi.org/10.1016/j.agee.2011.03.020

Publisher: Elsevier

All outputs in CentAUR are protected by Intellectual Property Rights law, including copyright law. Copyright and IPR is retained by the creators or other copyright holders. Terms and conditions for use of this material are defined in the End User Agreement.

\section{www.reading.ac.uk/centaur}

\section{CentAUR}

Central Archive at the University of Reading 
Reading's research outputs online 


\section{Pollination services in the UK: How important are honeybees? Agriculture, Ecosystems and Environment, Breeze, T. D., Bailey, A. P., Balcombe, K. G. and Potts, S. G. (2011) 142 (3-4). pp. 137-143}

Dear Downloader,

Thank you for downloading this publication from our repository.

The University of Reading is committed to increasing the visibility of our research and to demonstrating the value that it has on individuals, communities, organisations and institutions.

To support us in this commitment, we are running a pilot project to find out more about the people who download information from the University of Reading website. The publication you have downloaded is part of this project.

It would help us greatly if you could spend two minutes filling out the survey at the following link. Completion is voluntary and information supplied will be treated as confidential. Please indicate if you would be happy for us to contact you in the future. Alternatively, enquiries or responses can be addressed to impact@reading.ac.uk

\section{https://www.surveymonkey.com/s/GJRJ5GR}

Thank you for your interest in our research and we look forward to receiving your feedback.

Yours sincerely

Anthony Atkin, Research Impact Manager (University of Reading) 


\section{Pollination services in the UK: How Important are 2 Honeybees?}

3 Breeze T.D. ${ }^{1 *}$, Bailey A.P. ${ }^{2}$ Balcombe K.G. ${ }^{3}$ and Potts S.G. ${ }^{1}$

$4 \quad \underline{\text { Abstract }}$

5

6

7

Pollination services are known to provide substantial benefits to human populations and agriculture in particular. Although many species are known to provide pollination services, honeybees (Apis mellifera) are often assumed to provide the majority of these services to agriculture. Using data from a range of secondary sources, this study assesses the importance of insect pollinated crops at regional and national scales and investigates the capacity of honeybees to provide optimal pollination services to UK agriculture. The findings indicate that insect pollinated crops have become increasingly important in UK crop agriculture and, as of 2007, accounted for $20 \%$ of UK cropland and $19 \%$ of total farmgate crop value. Analysis of honeybee hive numbers indicates that current UK populations are only capable of supplying $34 \%$ of pollination service demands even under favourable assumptions, falling from $70 \%$ in 1984 . In spite of this decline, insect pollinated crop yields have risen by an average of 54\% since 1984, casting doubt on long held beliefs that honeybees provide the majority of pollination services. Future land use and crop production patterns may further increase the role of pollination services to UK agriculture, highlighting the importance of measures aimed at maintaining both wild and managed species.

$\underline{\text { Keywords }}$

Pollination Services

Honeybees

Ecosystem Services

Crop Pollination

\section{Introduction}

Human societies derive great benefit from a range of natural ecological functions, referred to as ecosystem services. Insect mediated pollination, the transfer of pollen within or between flowers via insect vectors, is one such ecosystem service, regulating a range of direct and indirect benefits to human societies (Fisher et al, 2009). Insect pollination is thought to benefit the yields of $75 \%$ of globally important crop species and is responsible for an estimated $35 \%$ of world crop production (Klein et al, 2007). The nature and extent of these benefits can vary between crops, ranging from increasing the quantity and quality of fruit or seed produced to hastening crop development and increasing genetic diversity within crop species (Free, 1993; Shipp et al, 1994; Hajjar et al, 2008). Economically, the value of insect pollination services to crop agriculture has been estimated at $\sim £ 400$ million per annum within the UK (POST, 2010) and $€ 153$ billion per annum

\footnotetext{
${ }^{1}$ Centre for Agri Environmental Research, University of Reading, Reading RG6 6AR, UK

${ }^{2}$ School of Agriculture, Policy and Development, Department of Agriculture, University of Reading

${ }^{3}$ School of Agriculture, Policy and Development, Department of Food Economics \& Marketing, University of Reading
} 
1 globally (Gallai et al, 2009). Insect pollination services are also essential to propagating numerous wild plant species (Ollerton et al, In Press), many of which contribute to human welfare indirectly as important components of landscape aesthetics (Willis and Garrod, 1993). Other insect pollinated wild plants, such as hawthorn (Crataegus monogyna), provide important winter forage for farmland birds and other wildlife (Jacobs et al, 2009) that contribute to human welfare through more indirect non-use values. Bees (Apidae) are generally regarded as the most important pollinators, in particular an estimated $80 \%$ of global agricultural pollination services are attributed to the domesticated European Honeybee (Apis mellifera) (Carreck and Williams, 1998). Furthermore, several other bee species, such as the buff-tailed Bumblebee (Bombus terrestris), have recently been commercially domesticated for large scale agricultural pollination (Delaplane and Mayer, 2000). However, a growing body of research indicates that wild pollination services could account for a substantially greater proportion of pollination services than previously thought, even in modern, intensive farm systems (e.g. Winfree et al, 2008) prompting some to suggest that the importance of honeybees in providing pollination services may have been over estimated (Westerkamp and Gottsberger, 2000).

Concerns regarding the stability of pollination services have existed for as long as the concept of ecosystem services themselves (Nabhan and Buchman, 1997). Although some have claimed that these concerns are exaggerated (Ghazoul, 2005), there has recently been mounting evidence of a global decline in wild pollinator populations (Potts et al, 2010a) and honeybee hive numbers are now thought to be in a long-term state of decline in many developed nations (Potts et al, 2010b; vanEngelsdorp and Meixner, 2010). Furthermore, although global honeybee hives numbers have grown by $\sim 45 \%$ since 1961 , the area of insect pollinated crops has grown by $>300 \%$ in the same period, now accounting for $6.1 \%$ of global crop land (Aizen and Harder, 2009). While trends in global yields do not demonstrate any significant global pollination shortage (Aizen et al, 2008), regional declines have been associated with localised shortfalls in pollinator populations (SteffanDewenter et al, 2005). Within Europe, the UK has experienced particularly well documented pollinator losses, with widely recorded declines in the diversity and distribution of wild bees, butterflies, hoverflies and wild plants during the last 50 years (Biesmeijer et al, 2006; Thomas et al, 2004; Carvell et al, 2006) and a 54\% fall in honeybee hive numbers in England between 1985 and 2005 (Potts et al, 2010b), raising concerns over the long-term stability of UK pollination services.

Although pollination services provide substantial benefits to UK crop producers and consumers, there have been few published accounts of the extent and distribution of these benefits across the UK. In order to bridge this gap, this study examines the proportion of UK crop area and market value stemming from crops which benefit from insect pollination so as to gauge how important insect pollinated crops are to UK agriculture. Similarly, although it is widely assumed that honeybees provide the majority of pollination services currently no research has demonstrated the validity of this speculation. While recent studies have suggested that honeybees may not always be optimal or even effective pollinators of certain crops (e.g. Apples; Thomson and Goodell, 2001), they are easily managed, are active earlier in the year than many wild pollinators, and can be moved between crops in bloom (Delaplane and Mayer, 2000). As such, honeybees can provide invaluable pollination services in the intensively managed systems that typify UK cropland. Declining numbers of honeybee hives during the last 20 years therefore have serious implications for both the provision of pollination services and the UK's ability to cope with changing demand for pollination services. This study explores this potential deficit by examining trends in the potential of UK honeybees to 
1 supply demands for pollination services at a level where yield and quality benefits to crops are

2 maximised.

$3 \quad$ 2. Methods

\subsection{The importance of insect pollinated crops to UK agriculture}

A total of 19 crops and crop groups recorded by the Department for Environment Food and Rural Affairs (DEFRA) which benefit from insect pollination to any extent were identified using Klein et al (2007) (Appendix 1). While certain varieties of some crops such as oilseed rape (Brassica napus) and cucumber (Cucumis sativus) are entirely self-fertile and do not require insect pollination (Free, 1993), it is assumed that only insect pollinated varieties are utilised, primarily because varietal data is unavailable for most crops (DEFRA, 2010a; 2009) and data on the pollination requirements of most varieties are also unavailable. The proportion of crop area and value derived from insect pollinated crops was estimated at a national level using data for all food and non-food crops reported in the 2008, 2000 and 1996 Basic Horticultural Survey (DEFRA, 2009; Ministry of Agriculture Fisheries and Food - MAFF, 1999, 1996) and the Agriculture in the UK report (DEFRA, 2010a). While area and value data for horticultural crop groups are reported in DEFRA (2010a), data from DEFRA, (2009) and $\operatorname{MAFF}(1999,1996)$ are used to allow for assessment of trends on a per crop basis. Although area data reported in DEFRA $(2009)$ and $\operatorname{MAFF}(1999,1996)$ is estimated for crop years it is approximately consistent with calendar year fresh fruit area data found in DEFRA (2010a). 1984 horticultural crop area data was taken as calendar year data from MAFF (1995) and adjusted by the average difference between crop and calendar year area data for years also reported in MAFF (1996). All value data were reported for calendar years and represent value paid to producers, not necessarily final market prices. The value of changes in stock and subsidies for arable crops were not included (DEFRA, 2010a).

At a regional level, crop specific data from the June censuses of each constituent country (England - DEFRA, 2008a; Scotland - Scottish Government, 2007; Northern Ireland - Department of Agriculture and Rural Development - DARD, 2008) and the orchard fruit and glasshouse surveys (DEFRA, 2007b, 2008b) were used to estimate the percentage of individual crop occurring within each region. Further crop specific area data concerning soft fruits and pulses were provided by members of the census teams (H. Hoult, L. Reid, C. McCormack, Pers. comm., 2009). As crop specific data is not collected for any insect pollinated crops in Wales, no analysis of the pollinator dependence of the country could be conducted (Welsh Assembly Government, 2008). For the census category Peas and Beans, which includes both insect pollinated and non-insect pollinated crops, this area was divided proportionately between the constituent crops based on their total national area reported in DEFRA (2009). Any orchard fruit or glasshouse crop area not specifically allocated in DEFRA (2007b, 2008b) was distributed among the remaining counties, weighted by their total area of top fruit or protected vegetables reported in DEFRA (2008a), Scottish Government (2007) and DARD (2008). These procedures assume that all crops can be grown in all regions, however, the range of climates across the UK will likely have a substantial influence upon farmers ability to grow some crops, particularly fruits. The percentage of each crop occurring within each region was then multiplied by the area and value of each crop as reported by DEFRA $(2009,2010$ a) which, in some cases, differ substantially from DEFRA (2008a) and DEFRA (2007a, 2008b) due to differences in survey methodology. Where areas of individual crops were not identified by any source, for example 
1 open grown vegetables which are only reported as a group, the sum market value of all crops within the group were used to estimate regional value. Mushrooms were excluded from this study as their planted area is not reported at either a national or regional level by any of the sources above, although their economic value is substantial (f104m in 2007; DEFRA, 2009). All value figures were inflated to 2007 values using consumer price indices (ONS, 2009).

\subsection{Pollination service capacity of UK Honeybees}

The maximum capacity of honeybees to satisfy optimal pollination service demand $\left(O P C_{\max , t}\right)$, a ratio of effective total honeybee hives over total pollination service demand from UK crops was estimated mathematically; let $\mathrm{c}=\mathrm{crop}, \mathrm{t}=$ year and $\mathrm{p}=$ phenological (flowering) period $(1 \ldots P)$ within $t$, each representing a month long interval, beginning from mid-March until mid-June. $P$ is determined based on the number of different crops a beekeeper could move their hives between within a single t. $\mathrm{P}$ is assumed to be 3 as this is maximum number of crops a professional beekeeper will be able to move between in a year (John Howat, Pers. Comm., 2010). Although varieties of some crops may bloom after this end point (e.g. Wagstaffe and Battey, 2006) varietal data is not available for most crops and therefore could not be incorporated. $A_{\text {ctp }}$ represents the area of each crop grown in each $p$ within $t$ (as reported by DEFRA 2009, 2010a). Areas of crops listed as Glasshouse Crops, i.e. those grown exclusively in fully enclosed glasshouses (tomatoes, cucumbers and sweet peppers) were excluded as honeybees are seldom used in such environments due to management difficulties (Delaplane and Mayer, 2000). Crops grown under partially enclosed poly-tunnels, such as strawberries, were included in this area as honeybees can be used in such systems and estimates of the applicable area is not available for each year under consideration. $R_{c}$ represents the recommended hive density for optimal pollination of crop $\mathrm{c}$ as derived from published sources (Appendix 1). $D_{t p}$ is the total pollination services demanded (expressed in number of honeybee hives) in each $p$ within each $t$, defined as:

$\mathrm{H}_{\mathrm{t}}$ represents the reported number of managed UK honeybee hives (as reported by MAFF and the National Bee Unit, see Potts et al, 2010b). In years where $H_{t}$ is not formally reported for one or more constituent nations then it is assumed hive numbers have remained constant between $\mathrm{t}$ and $\mathrm{t}-\mathrm{t}$. Under this assumption, which differs from those employed in Potts et al. (2010b), total hive numbers in the UK have grown by $22 \%$ since 1984 to 289,750 in 2007 , however this number remains constant from 2002 onwards. In the absence of data on stocking practices, growers are assumed to stock no more than $R_{c}$ per hectare. $E_{t p}$ represents hives in excess of those required in phenology period $p$ and is calculated as: 
1 Where $I_{t p}=0$ if $E_{t p}<0$ and 1 otherwise. Consequently, $0 \leq Q_{t} \leq P H_{t}$. Under these definitions $O P C_{\max , t}$ is

2 defined as:

$\mathrm{OPC}_{\max }$ was recalculated at a range of $\mathrm{R}_{\mathrm{c}}$, representing the lowest, highest and average recommended hive density per hectare. National area of winter sown oilseed rape was acquired from DEFRA (2010b) and Hoult H. pers. comm. (2010) with an average area applied to each year not reported.

\section{Results}

\subsection{The importance of insect pollinated crops to UK agriculture}

Analysis of cropland in the UK since 1984 indicates that insect pollinated crop area has risen by $57.5 \%$ covering 848,946 ha of UK cropland in 2007 , growing at an average rate of 21,250 ha per year (Figure 1A). This represents $20.4 \%$ of 2007 UK cropland, more than double the proportion of total crop land occupied by these crops in 1984 (7.2\%, Figure 1C). The exclusion of insect pollinated minority crops, such as Borage, and the indirect techniques used to produce horticultural crop area estimates (DEFRA, 2010c) will influence this finding to an unknown extent, however, the magnitude of these effects is likely too small to significantly affect the findings. Much of this growth stems from substantial rises in oilseed rape and field bean area, collectively rising by 503,000ha since 1984 (DEFRA, 2010a) at the expense of barley and other arable crops. In comparison, the area of fruit crops, all of which benefit from insect pollination, has fallen by $\sim 17,900$ ha during the same period with particularly sharp declines in dessert and culinary apples, likely due to falling prices/tonne and increased costs (Nix, 1984, 2010; DEFRA, 2009; MAFF, 1999, 1996). These results are distorted somewhat by a spike in the area of oilseed rape in 2007, which has since returned to levels similar to previous trends (DEFRA, 2010a). Overall, the total area of cropland in the UK has fallen by 831,366ha within the same period, with particularly strong declines in the area of barley (-54.6\%), potatoes (29.3\%) and other vegetable crops (-23.6\%). Much of this land has become pastureland, although $\sim 61,000$ ha of total agricultural land have been taken out of production (DEFRA, 2010a).

Regionally, South East England has the greatest area of insect pollinated crops, occupying $\sim 30 \%$ of cropland (Table 1) due to large areas of fruit growing within the region (DEFRA, 2008a). In spite of these rises in insect pollinated crop area, by 2007 the total value of insect pollinated crops has fallen by $f 626 \mathrm{M}(2007 \mathrm{f}$ ) since 1984 to $\mathrm{f1057M}$ (Figure 1B) as a result of falling prices and declining planted area of high yielding fruit crops such as tomatoes and dessert apples. This trend is in part a product of the methodology used; while prices for insect pollinated crops have grown by an average of $102 \%$ since 1984 , this growth is substantially smaller than the growth in inflation $(231 \%$ cumulative) by which crop value was adjusted. Consequently when unadjusted for inflation, this overall downward trend is reversed, with total value of insect pollinated crops rising by $f 329 \mathrm{M}$ since 1984. Nonetheless, the proportion of total crop value represented by these crops has grown, albeit inconsistently, from $15.1 \%$ in 1984 to $19.3 \%$ in 2007 (Figure 1D) due also to widespread increases in oilseed rape and field bean production in place of other arable crops (DEFRA, 2010a). At a regional scale, insect pollinated crops represent the greatest proportion of crop value in South East England, the West Midlands, and Northern Ireland. However, their absolute value was greatest in Eastern 
1 regions of England (Table 1). This disparity stems from varying scales of agriculture between regions

2 and the higher per hectare value of fruit crops, which are commonly grown in eastern regions,

3 compared to arable crops (DEFRA, 2009, 2010a).

\subsection{The pollination service capacity of UK honeybees}

5

6

7

8

In spite of growth in honeybee hives arising from the assumptions made in this study, the capacity of honeybees to supply pollination service demands ( $O P C_{\max }$ ) has fallen by more than $50 \%$ during the study period from a peak $70.3 \%$ in 1984 to $34.1 \%$ by 2007 (Figure 2). This trend is a product of substantial growth in insect pollinated crop area, particularly oilseed rape and field beans, each of which requires several hives per hectare to ensure optimal pollination. Under higher recommended density assumptions, managed honeybees may only contribute as little as $11.7 \%$ of optimal pollination services. In all years, only a small proportion (1-11\%) of available hives are required in the first phenological period and sufficient hive numbers are available throughout the year to provide optimal pollination services to UK fruit crops (Appendix 1). Regionally demand for pollination services, in terms of total hives required, is greatest in Eastern regions of the UK (Table 2) which, as highlighted above, have higher areas of insect pollinated crops (DEFRA, 2008a).

\section{[Figure 1]}

\section{[Table 1]}

\section{[Table 2]}

\section{[Figure 2]}

\section{$\underline{4 . D i s c u s s i o n}$}

\subsection{Trends in insect pollinated crops}

This study indicates that insect pollinated crops have become an increasingly substantial component of UK crop agriculture since 1984 , accounting for $~ 20 \%$ of UK crop land and $\sim 19 \%$ of total crop value in 2007. Much of this growth stems from rising areas of mass flowering arable crops, likely due to past Common Agricultural Policy subsidisation. Oilseed rape has also benefited from rising EU demands for biofuels (Stoate et al, 2009) and the advent of cultivars with low glucosinolates and erucic acid content, allowing for use as animal feed (Burgess and Morris, 2009). Fruit crops have also become more important to total UK crop value thanks to advances in growing systems and, in the case of strawberries, breeding cultivars that bear fruit outside of the normal growing season (Wagstaffe and Battey, 2006).

\subsection{Trends in the pollination service capacity of UK honeybees}

In spite of growing demand for pollination services and rising hive numbers, the $\mathrm{OPC}_{\max }$ of honeybees has declined by more than $50 \%$ since 1984 and will fall further if recent honeybee declines are considered (see Potts et al, 2010b). This finding is subject to a set of potentially distorting assumptions. First, most data on managed honeybee hive numbers are taken from member information provided by beekeeping organisations and as such excludes hives managed by non-members. Second, feral honeybee colonies are not included in these estimates as their distribution and abundance are largely unknown and consequently their impact upon pollination 
services cannot currently be estimated (Carreck, 2008). Third, as highlighted in the methodology, the area of each crop was assumed to solely comprise of insect pollinated varieties, possibly exaggerating the area of crops requiring insect pollination. Each of these assumptions may produce an underestimation of actual pollination services provided by honeybees. By contrast, a number of other factors can exaggerate the $\mathrm{OPC}_{\max }$ of honeybees. Foremost, in light of the sharp decline in honeybee hive numbers reported in Potts et al (2010b), the assumptions made regarding hive numbers in years where no official reports were available are likely to produce overestimations in recent years. Furthermore, the recommended hive density values are derived from a wide range of sources from different countries and methods (Delaplane and Mayer, 2000). While these values are seldom specific for the UK, they are generally accepted to be appropriate and have rarely been challenged. Colonies were assumed to be at optimal health, ignoring the potential impacts of pests and diseases upon foraging activity (Ellis et al, 2003 but see Ellis and Delaplane, 2008). Although data on honeybee disease incidence are available from the National Bee Unit, as inspection is voluntary and there are few estimates of the relation between health and pollination efficiency, such data cannot yet add meaningfully to the findings. Most critically, all UK honeybee hives were assumed to be actively managed for pollination service provision throughout the crop year. In actuality, most UK beekeepers are amateurs or professional honey producers that typically position their hives in nectar rich semi-natural habitat, although some crops, such as apples are often cited as important nectar sources for honey production (Carreck et al, 1997). Currently, only about $2 \%$ of UK hives $(\sim 5,700)$ are known to be professionally managed for pollination services (John Howat, Pers. Comm. 2010 ), accounting for $<0.5 \%$ of $O P C_{\max }$ even under lower required density assumptions. As other beekeepers are unlikely to move their hives as often, reducing the value of $\mathrm{P}$ (see methodology) from 3 to 2 may better reflect this, however, the large excess of hives in the first phenological period implies that only a minority of hives are moved more than once. Finally, no account is made of the contribution of other managed bees, such as the $\sim 10,000$ B. terrestris hives imported into the UK each year (POST, 2010). As managed $B$. terrestris are most often used for pollination within fully enclosed systems which are neither accessible to wild pollinators nor suitable to honeybees, their inclusion is unlikely to affect conclusions reached.

\subsection{Trends in insect pollinated crop yields}

Contrary to the fall in the $\mathrm{OPC}_{\max }$ of honeybees, per ha yields of insect pollinated crops have risen by an average of 54\% since 1984 (Figure 3). Regression analysis using R (R project, 2010) indicates that average yields of insect pollinated crops as a group have grown at a significantly faster rate per annum than other crops ( $t=3.611, \mathrm{P}=<0.001$, see appendix 3 for details). The inconsistent nature of honeybee hive data and substantial auto-correlation arising from the resultant assumptions, prevents valid assessment of correlations between yields and honeybee numbers. In line with findings by Aizen et al. (2008), the observed trends in yield suggest that there has not yet been a detectable loss of pollination services within the UK. Subsequently, these findings infer that wild bee populations may make a much greater contribution to UK crop pollination services than previously thought. This is somewhat speculative given the observed declines in wild bees during the study period (Biesmeijer et al, 2006; Carvel et al, 2006), although as many wild bees can be substantially more effective pollinators than honeybees (e.g. Thompson and Goodall, 2001) it is possible that, even in reduced abundance, these species can provide effective pollination services to crops. Furthermore, increased availability of mass floral resources (Diekotter et al, 2010), may have created a population sink effect in wild bees in light of reduced competition from honeybees 
1 (Goulson and Sparrow, 2009) and declining wildflower availability (Biesmeijer et al, 2006).

2 Alternatively, intensification and agronomic advances, such as increasing fruit tree density and 3 selection of higher yielding arable crop cultivars, might have enhanced yields sufficiently to mask

4 declines in pollination services. Growers may themselves have reacted to pollination service declines 5 by utilising more self-fertile or parthenocarpic cultivars. However, as pollination requirements are

6 seldom considered when developing new cultivars (e.g. Home Grown Crops Association, 2010) this

7 seems unlikely. Under these circumstances, honeybees may be more major contributors to

8 pollination services than is apparent from the data presented here. Another possibility is that

9 pollination service deficits may only have arisen in a few crops which honeybees are rarely employed

10 to pollinate, such as mass flowering arable crops (John Howat, Pers. Comm. 2010). This is supported

11 in part by the 10-22\% decline in field beans, oilseed rape and linseed yields (Appendix 2) since 1984.

12 [Figure 3]

\subsection{Future demand for insect pollinated crops}

A number of market factors and policy are likely to influence the future importance of pollination services to UK crop agriculture. Firstly, demand for oilseed rape may rise further as $\sim 1.4$ million ha of the crop is required to meet the UKs EU 2020 biodiesel target (Foresight Land Use Futures Project, 2010) although non-controllable pest and disease species are likely to restrict the regularity with which it can be included in rotations (Berry and Spink, 2006). Similarly, although the UK has become increasingly reliant upon low-cost imports to satisfy demand for many insect pollinated crops (DEFRA, 2009), demand for locally sourced produce, arising from perceived environmental, economic and health benefits (Brown et al, 2009) may bolster the market for home production of many crops. Finally, government policy aimed at improving dietary health is projected to encourage a substantial rise in the area of fruit crops, particularly in southern and eastern regions of England, at the expense of pasture farming, field bean and oilseed area as demand for meat and feed falls (Arnoult et al, 2010). Accordingly, insect pollinated crops account for a lower proportion of crop area under this scenario compared to the reference run.

\subsection{Conservation recommendations}

In light of the current and potential future importance of insect pollination, bee conservation efforts are likely to produce substantial long-term benefits to UK agriculture. The findings of this study suggest that these efforts should be focused on a suite of wild and managed pollinators, rather than over-relying on honeybees as sole service providers. Currently there is no national UK conservation policy targeted towards pollination services, however, recent government investment in pollination research (POST, 2010) combined with a shift towards ecosystem oriented conservation (DEFRA, 2007b) are promising first steps. While current agri-environmental schemes provide some options that are beneficial to pollinators, such as nectar flower mixes (Potts et al, 2009), without added incentives, these options suffer from poor uptake compared to lower-cost alternatives (Hodge and Reader, 2010). Clearly defined, quantifiable ecosystem service outputs and specific incentives for more beneficial activities are likely to eliminate this shortcoming, creating a cost-effective market for the production of pollination and other ecosystem services (Smith, 2006). Unfortunately, primary conservation research seldom translates into effective policy as political actors often fail to act on an effective time scale (Knight et al, 2006) or to the required extent (Wu et $a l, 2003)$. As such, it is essential that future research demonstrate the benefits of pollination services 
1 to growers, particularly for crops which benefit in a significant but less overt manner, such as oilseed rape (Klein et al, 2007), to encourage them to adopt pollinator conservation measures.

As wild pollinator populations often lack the abundance necessary to pollinate intensive, large-scale crop systems and their population dynamics can very strongly between years (e.g. Rader et al, 2009), honeybees are likely to remain an important component of UK pollination services. Apiculture is a declining industry in the UK (Potts et al, 2010b) and therefore securing and expanding honeybee populations will probably entail substantial increases in payments for pollination services, particularly for crops such as oilseed rape where beekeepers seldom receive payment (Carreck et al, 1997 ) in order to provide sufficient incentives to beekeepers. Although producer willingness to pay for these services may rise with increasing demand, these increased costs, which are vulnerable to price shocks in years of disease outbreak (Sumner and Boriss, 2006), combined with rising prices for inputs (Nix, 2010) may dissuade many producers. Expanded use of other pollinating insects, such as bumblebees or red mason bees (Osmia rufa), which are purchased rather than rented, may provide growers with a more-cost effective means of ensuring optimal pollination services, particularly when honeybees are sub-optimum pollinators of a particular crop (Delaplane and Mayer, 2000). Geographically specific standardised assessments of optimal pollination requirements for different crop cultivars will also be necessary to ensure producers and beekeepers are able to maximise the service provision by managed pollinators. Nevertheless, the use of any managed pollinators should be undertaken with considerable caution as their release can influence forage resources (Goulson and Sparrow, 2009), disease prevalence (Colla et al, 2006) and population size (Stubbs and Drummond, 2001) in nearby wild pollinator populations. Consequently, it is essential that wild pollinator conservation policy evolves in parallel with a focused expansion of the UK beekeeping industry in order to supply optimal pollination service demands to UK agriculture into the long-term future.

\section{$\underline{\text { 5. Conclusions }}$}

This study has demonstrated that, in spite of rising demand for pollination services, the capacity of UK honeybee populations to provide optimal pollination services has fallen dramatically during the last 20 years. In contrast to expected trends, insect pollinated crop yields have risen substantially during this time, implying that wild pollinators make a substantially greater contribution to UK crop pollination services than previously assumed. These findings should be treated with a degree of caution as the assumptions made may marginally under-or overestimate the relative contribution of honeybees to actual pollination services. As insect pollinated crops are likely to become increasingly important to UK agriculture in the immediate future, clarifying these assumptions will be useful in directing new developments in effective pollination management at a field and landscape scale.

\section{Acknowledgements}

The authors wish to acknowledge the invaluable data contributions of Helen Hoult (DEFRA), Linda Reed (Scottish Assembly Government) and Connor McCormac (DARD). John Howat of the Bee Farmers Association provided crucial insight into the UK beekeeping industry and crop phenology. Robin Dean of Red Beehive Pollination provided valuable contact information. Rex Brennan, Nick Battey, Paul Hadley, Matthew Ordidge, Gillian Rose and Stuart Roberts provided links to information on the phenology of crops. Fiona Underwood provided statistics support. Three anonymous referees 
1 provided invaluable feedback on earlier drafts of the manuscript. Tom Breeze is supported by a

2 University of Reading Research Studentship. The research leading to these results has received

3 partial funding from the European Community's Seventh Framework Programme (FP7/2007-2013)

4 under grant agreement no 244090, STEP Project (Status and Trends of European Pollinators,

5 www.step-project.net). The authors declare no conflict of interest.

\section{$6 \underline{7 . \text { References }}$}

7 Aizen M.A. and Harder L.D. (2009) The Global Stock of Domesticated Honey Bees is Growing Slower

8 than Agricultural Demand for Pollination; Curr. Biol. 19 (11) 915-918

9 Aizen M.A., Garibaldi L.M., Cunningham S.A. and Klein A.M. (2008) Long Term Trends in Crop Yield

10 and Production Reveal No Current Pollination Shortage but Increasing Pollinator Dependency; Curr.

11 Biol. 18 (20) 1-4

Arnoult, M H, Jones, P J, Tranter, R B, Tiffin, R, Traill, W B \& Tzanopoulos, J (2010) Modelling The Likely Impact of Healthy Eating Guidelines on Agricultural Production and Land Use in England and Wales. Land Use Policy 27, (4), 1046-1055

Berry P.M. and Spink J.H. (2006) A Physiological Analysis of Oilseed Rape Yields: Past and Future; J. Agr. Sci. 144, (5), 381-392

Biesmeijer, J. C., Roberts, S. P. M., Reemer, M., Ohlemuller, R., Edwards, M., Peeters, T., Schaffers, A. P., Potts, S. G., Kleukers, R., Thomas, C. D., Settele, J. and Kunin, W. E. (2006) Parallel Declines in Pollinators and Insect Pollinated Plants in Britain and The Netherlands; Science 313, (5785), 351-354

Brown E., Dury S. and Holdsworth M. (2009) Motivations of Consumers That Use Local, Organic Fruit and Vegetable Box Schemes in Central England and Southern France; Appetite 53, (2), 183-188

Burgess P.J. and Morris J. (2009) Agricultural Technology and Land Use Futures: The UK Case; Land Use Policy 26S, S222-S229

Carreck N. (2008) Are Honeybees (Apis mellifera L.) Native to the British Isles?; J. Apicult. Res. 47, (4), 318-322

Carreck N. and Williams I. (1998) The Economic Value of Bees in the UK; Bee World 79 (3), 115-123

Carreck N.L., Williams I. H. and Little D.J. (1997) The Movement of honey bee colonies for crop pollination and honey production by beekeepers in Great Britain; Bee World 78, (2), 67-77 Forage Availability for Bumblebees at a National Scale; Biol. Conserv. 132, (4), 481-489 2007; http://www.dardni.gov.uk/index/publications/pubs-dard-statistics/agricultural-census- 
DEFRA (2007a) Orchard Fruit Survey - February 2007; DEFRA, London

DEFRA (2007b) Conserving Biodiversity: The UK Approach; DEFRA, London

DEFRA (2008a) June Survey of Agriculture and Horticulture 2007;

http://www.defra.gov.uk/evidence/statistics/foodfarm/landuselivestock/junesurvey/results.htm

Accessed 30/06/10; Last Updated 18/03/10

DEFRA (2008b) Glasshouse Survey 2007; DEFRA, London

DEFRA (2009) Basic Horticultural Statistics 2009

http://www.defra.gov.uk/evidence/statistics/foodfarm/landuselivestock/bhs/2009/index.htm

DEFRA (2010a) Agriculture in the UK 2009

http://www.defra.gov.uk/evidence/statistics/foodfarm/general/auk/latest/index.htm Accessed:

30/06/10, Last Updated 18/03/10

DEFRA (2010b) United Kingdom Cereal Yields 1885 onwards;

http://www.defra.gov.uk/evidence/statistics/foodfarm/food/cereals/documents/cyield c.xls Last

Accessed; 30/06/10, Last Updated; 12/01/2010

DEFRA (2010c) Basic Horticultural Statistics 2010

http://defra.gov.uk/evidence/statistics/foodfarm/landuselivestock/bhs/documents/bhs.pdf

Delaplane K.S. and Mayer D.E. (2000) Crop Pollination by Bees, CABI Publishing; Wallingford

Diekötter T., Kadoya T., Peter F., Wolters V. and Jauker F (2010) Oilseed Rape Crops Distort PlantPollinator Interactions; J. Appl. Ecol. 47, (1), 209-214

Ellis J.D., Hepburn R., Delaplane K.S., Neumann P. and Elzen P.J. (2003) The Effects of Adult Small Hive Beetles, Aethina tumida (Coleoptera: Nitidulidae), on Nests and Flight Activity of Cape and European Honey Bees (Apis mellifera); Apidologie 34, (4), 399-408

Ellis J.D. and Delaplane K.S. (2008) Effects of Nest Invaders on Honey Bee Pollination Efficancy; Agr. Ecosyst. Envion. 127, (3-4), 201-206

Fisher B, Turner R.K. and Morling P. (2009) Defining and Classifying Ecosystem Services for Decision Making; Ecol. Econ. 68, (3), 634-653

Fraser G.A. (2005) An Analysis of Dormancy and Chilling of Ribes nigrum L.; PhD Thesis, School of Biological Sciences, University of Reading

Free J. (1993) Crop Pollination by Insects ( $2^{\text {nd }}$ Edition); Academic Press, London

Gallai N., Salles, J. M., Settele, J. and Vaissiere, B. E. (2009) Economic Valuation of the Vulnerability of World Agriculture Confronted with Pollinator Decline; Ecol. Econ. 68, (3), 810-821

Ghazoul J. (2005) Buzziness as Usual? Questioning the Global Pollination Crisis; Trends Ecol. Evol. (7) 367-373 
1 Goulson D. and Sparrow K.R. (2009) Evidence for Competition Between Honeybees and Bumblebees;

2 Effects on Bumblebee Worker Size; J. Insect Conserv. 13, (2), 177-181

3

4

5

6

Hajjar R., Jarvis D.I. and Gemmill-Herren B (2008) The Utility of Crop Genetic Diversity in Maintaining Ecosystem Services; Agr. Ecosyst. Environ. 123 (4) 261-270

Home Grown Crops Authority (2010) HGCA Recommended List - Winter Oilseed Rape 2011/12 East/West Region

http://www.hgca.com/document.aspx?fn=load\&media id=6719\&publicationld=4821

Hodge I. and Reader M. (2010) The Introduction of Entry Level Stewardship in England: Extension or Dilution in Agri-Environment Policy? Land Use Policy 27, (2), 270-282

Jacobs, J. H., Clark, S. J., Denholm, I., Goulson, D., Stoate, C. and Osborne, J. L. (2009) Pollination Biology of Fruit Bearing Hedgerow Plants and the Role of Flower Visiting Insects in Fruit Set; Ann. Bot. 104, (7), 1397-1404

Klein, A. M., Vaissiere, B. E., Cane, J. H., Steffan-Dewenter, I., Cunningham, S. A., Kremen, C., Tscharntke, T. (2007) Importance of Pollinators in Changing Landscapes for World Crops; P Roy Soc B-Biol Sci 274, (1608), 303-313

Knight A. T., Cowling R. M. and Campbell B. M. (2006) An Operational Model for Implementing Conservation; Conserv. Biol 20, (2), 408-419

MAFF (1995) Basic Horticultural Statistics for the United Kingdom Calendar and Crop Years 19841994; Ministry of Agriculture Food and Fisheries, London

MAFF (1996) Basic Horticultural Statistics for the United Kingdom Calendar and Crop Years 19851995; Ministry of Agriculture Food and Fisheries, London

MAFF (1999) Basic Horticultural Statistics for the United Kingdom Calendar and Crop Years 19881998; Ministry of Agriculture Food and Fisheries, London

Nabhan S.L. and Buchman G.P. (1997) Services Provided by Pollinators in Daily G eds Nature's Services; Island Press, Washington

National fruit Collection (2010) http://www.nationalfruitcollection.org.uk/ last accessed 30/06/2010 Nix J. (2010) Farm Management Pocketbook (41 $1^{\text {st }}$ Edition); The Andersons Centre, Melton Mowbery Nix J. (1984) Farm Management Pocketbook (15 ${ }^{\text {th }}$ Edition); The Andersons Centre, Melton Mowbery Ollerton J., Winfree R. and Tarrant S. (In Press) How Many Flowering Plants are Pollinated by Animals?; Oikos

ONS (2009) Composite Price Index and annual change 1800 to 2008 (Release CDKO); http://www.statistics.gov.uk/StatBase/TSDTimezone.asp?vlnk=mm23\&Pos=\&ColRank=1\&Rank=-1 Last Accessed 30/06/10; Last Updated 09/06/2010 POST (2010) Insect Pollination POST Note 348; Parliamentary Office of Science and Technology; London 
1 Potts, S. G., Biesmeijer, J. C., Kremen, C., Neumann, P., Schweiger, O. and Kunin, W. E. (2010a) Global

2 Pollinator Declines; Trends, Impacts and Drivers; Trends Ecol. Evol. 25, (6), 345-353

3 Potts S.G., Roberts S.P.M., Dean R., Marris G., Brown M.A., Jones R., Neumann P., and Settele J.

4 (2010b) Declines of Managed Honeybees and Beekeepers in Europe; J. Apicult. Res. 49, (1), 15-22

5 Potts S.G., Woodcock B.A., Roberts S.P.M., Tscheulin T., Pilgrim E.S., Brown V.K. and Tallowin J.R.

6 (2009) Enhancing Pollinator Biodiversity in Intensive Grasslands; J. Appl. Ecol. 46, (2), 369-379

7 R project (2010) http://www.r-project.org/; accessed 07/01/10, last updated; 16/12/10

8 Rader R, Howlett B.G, Cunningham S.A, Westcott D.A, Newstrom-Lloyd L.E, Walker M.K, Teulon

9 D.A.J. and Edwards W. (2009) Alternative Pollinator Taxa are Equally Efficient but not as Effective as

10 the Honeybee in a Mass Flowering Crop; J. Appl. Ecol. 46, (5), 1080-1087

11 Scottish Government (2007) Final results of the 2007 June Agricultural Census

12 http://www.scotland.gov.uk/Publications/2007/10/agriccensus2007; Accessed 30/06/10, Last

13 Updated $24 / 10 / 07$

14 Shipp J.L., Whitfield, G. H. and Papadopoulos, A. P. (1994) Effectiveness of the Bumble Bee, Bombus-

15 impatiens $\mathrm{Cr}$ (Hymenoptera, Apidae), as a Pollinator of Greenhouse Sweet-Pepper; Sci Hort-

16 Amsterdam 57, (1-2), 29-39

17 Smith K.R. (2006) Public Payments for Environmental Services From Agriculture: Precedents and

18 Possibilities; Am. J. Agr. Econ. 88, (5), 1167-1173

Steffan-Dewenter I. Potts S.G. and Packer L. (2005) Pollinator Diversity and Crop Pollination Services

are at Risk; Trends Ecol. Evol. 20, (12), 651-652

Stoate C., Baldi A., Beja P., Boatman N.D., Herzon I., van Doorn A., de Snoo G.R., Rakosy L. and

Ramwell C. (2009) Ecological Impacts of Early 21st Century Agricultural Change in Europe; J Environ

Manage 91 (2), 22-46

Stubbs and Drummond (2007) Conserving Native Pollinators of Blueberry: A Case Study

Sumner D.A. and Boriss H. (2006), Bee-conomics and the Leap in Pollination Fees., Giannini

http://www.agecon.ucdavis.edu/uploads/update articles/v9n3 3.pdf)

Thomas, J. A., Telfer, M. G., Roy, D. B., Preston, C. D., Greenwood, J. J. D., Asher, J., Fox, R., Clarke, R. T. and Lawton, J. H. (2004) Comparative Losses and British Butterflies, Birds and Plants and the Global Extinction Crisis; Science 303, (5665), 1879-1881

Thomson J.D. and Goodall K. (2001) Pollen Removal and Deposition by Honeybee and Bumblebee visitors to Apple and Almond Flowers; J. Appl. Ecol. 38, (5), 1032-1044 
1 Welsh Assembly Government (2008) Agricultural Small Area Statistics 2002 to 2007

2 http://wales.gov.uk/topics/statistics/headlines/agric2009/hdw20090422/?lang=en

3 Wagstaffe A. and Battey N.H. (2006) Characterisation of the Thermodormancy Response in the

4 Everbearing Strawberry 'Everest'; J Hortic Sci Biotec 81, (6), 1086-1092

5 Westerkamp C. and Gottsberger G. (2000) Diversity Pays in Crop Pollination; Crop Science 40, (5),

$6 \quad 1209-1222$

7 Willis K.G. and Garrod G.D. (1993) Valuing Landscapes: A Contingent Valuation Approach; J Environ

$8 \quad$ Manage $37(1) 1-22$

9 Winfree R. Williams N.M., Gaines H., Ascher J.S. and Kremen C. (2008) Wild Bee Pollinators Provide 10 The Majority of Crop Visitation Across Land-Use Gradients in New Jersey and Pennsylvania; J Appl.

11 Ecol. 45, (3),793-802

12 Wu, J. J., Skelton-Groth, K., Boggess, W. G., Adams, R. M. (2003) Pacific Salmon Restoration: Trade13 offs Between Economic Efficiency and Political Acceptability; Contemp. Econ. Policy 21, (1), 78-89

Figure 1: Graphical representation of trends in insect pollinated crop area (a) and market value in the

16 UK (b) and the proportion of total UK crop area (c) and value (d) represented by these crops between 1984 and 2007

Figure 2: Maximum capacity of honeybees to satisfy optimal pollination service demand $\left(O P C_{\text {max,t }}\right)$ to UK crops by honeybees between 1984 and 2007 at the lowest, average and upper recommended 20 hive densities (RD) per hectare.

21 Figure 3: Average \% change in per ha yields of insect pollinated crops and all other crops in the UK 22 using 1984 as a base year 